\title{
PRICES ON GASOLINE IN RUSSIA AND ABROAD: COMPARATIVE ANALYSIS
}

Price growth of gasoline on Russian domestic market in the wake of declining world crude oil prices is due to the ruble's devaluation and excise rate growth. In Russia, the share of indirect gasoline taxes has gone up from $30-40 \%$ to 35-45\% over last two years. Regarding the share of taxes in the price at the pump, Russia is found in between leading EU countries (where this share reaches $65 \%$ ) and the US (20\%), and is close to Canada (37\%). At present consumer prices of gasoline in Russia constitute $90 \%$ compared to the US volume, $66 \%$ compared to those in Canada, $44 \%$ in comparison with such prices in Japan, and $39 \%$ against the average price level of five leading EU countries.

The gasoline prices on domestic market in Russia are formed under the effect of a number of factors. Key among them are world prices of crude oil and gasoline, export duty rates on crude oil and gasoline, ruble exchange rate, indirect taxes on gasoline, demand on gasoline on domestic market, and pricing policy of vertically integrated companies. The world crude oil prices determine non-tax (minus indirect taxes) prices on petroleum products on the world market. On the domestic market, producers set prices on tradable petroleum products including gasoline at the level, which ensures equal profitability with export: the world (non-tax) price on a corresponding product minus export duty and transportation costs (net-back price). Export duty determines stable gap between world and domestic non-tax prices on crude oil and petroleum products, maintains domestic prices on these products at the level, which is significantly below world prices ${ }^{1}$. Final (consumer) prices of gasoline on the domestic market hinge upon the level of indirect taxes (excise, VAT) and the margin set in the retail sector of petroleum products.

Over recent years, the consumer prices of gasoline in Russia were prone to growth (Table 1). At the same time, parameters of major factors, which determine domestic gasoline prices have significantly changed over recent two years. The world crude oil prices have declined twofold. Meanwhile, the ruble exchange rate has significantly fallen. Export duties have been cut and excises have gone up (Table 2). Reduction of export duties has been carried out in the framework of the ongoing tax maneuver ${ }^{2}$, excises on gasoline have been raised in order to replenish the revenue part of the state budget amid falling world crude oil prices.

These changes affected gasoline prices differently. For example, plunge of crude oil prices has resulted in a decrease of gasoline prices. However, as a result of an aggregate effect of factors final domestic gasoline prices have gone up together with excises. Prices of crude oil and petroleum products are nominated in US dollars on the world market. As a result of falling

1 See: Bobylev Yu. N., Idrisov G.I., Sinelnikov-Murylev S.G. Export Duties on Crude Oil and Petroleum Products: Cancel Expediency and Scenario Analysis. Moscow. Gaidar Institute Publishers, 2012.

2 See: Bobylev Yu. Idrisov G., Kaukin A., Rasenko O. Oil, Budget, and Tax Maneuver. Russian Economic Developments. № 11, 2015, pp. 47-50. 
CONSUMER PRICES OF GASOLINE IN RUSSIA IN 2014-2016

\begin{tabular}{|c|c|c|c|c|}
\hline & $\begin{array}{c}2014 \\
\text { January }\end{array}$ & $\begin{array}{c}2015 \\
\text { January }\end{array}$ & $\begin{array}{c}2016 \\
\text { January }\end{array}$ & $\begin{array}{c}2016 \\
\text { July }\end{array}$ \\
\hline Gasoline AИ-92, Rb/I & 29.53 & 32.35 & 33.86 & 35.13 \\
\hline Gasoline $\mathrm{AИ-95}$ and higher, $\mathrm{Rb} / \mathrm{I}$ & 32.64 & 35.16 & 36.81 & 38.14 \\
\hline Reference:Price of Urals, USD/bbl. & 105.9 & 46.6 & 28.8 & 43.6 \\
\hline
\end{tabular}

Source: Rosstat.

Table 2

RATES OF TAXES AFFECTING GASOLINE PRICE, IN 2014-2016

\begin{tabular}{|l|c|c|c|c|}
\hline & 2014 & 2015 & $\begin{array}{c}2016 \\
\text { January- } \\
\text { March }\end{array}$ & $\begin{array}{c}2016 \\
\text { April- } \\
\text { December }\end{array}$ \\
\hline $\begin{array}{l}\text { Crude export duty (coefficient in } \\
\text { export duty rate formula) }\end{array}$ & 0.59 & 0.42 & 0.42 & 0.42 \\
\hline $\begin{array}{l}\text { Gasoline export duty (coefficient in } \\
\text { relation to crude oil export duty rate) }\end{array}$ & 0.90 & 0.78 & 0.61 & 0.61 \\
\hline $\begin{array}{l}\text { Excises on gasoline, Rb/t: } \\
\text { Class 4 }\end{array}$ & 9916 & 7300 & 10500 & 13100 \\
\hline Class 5 & 6450 & 5530 & 7530 & 10130 \\
\hline
\end{tabular}

Sources: RF Tax Code (Edit. 2014-2016), RF Law «On Customs Tariff (Edit. 2014-2016).

world crude oil prices gasoline prices in dollar terms have fallen over last two years in Russia (actually the same as in the USA). Meanwhile, significant depreciation of the national currency against the dollar as well as growth of excises have determined increase of gasoline prices on the domestic market in the ruble terms (Fig. 1).

Prevailing structure of consumer gasoline price in Russia in comparison with leading industrial countries is characterized by the data given in Table 3. The European countries demonstrate high prices of gasoline

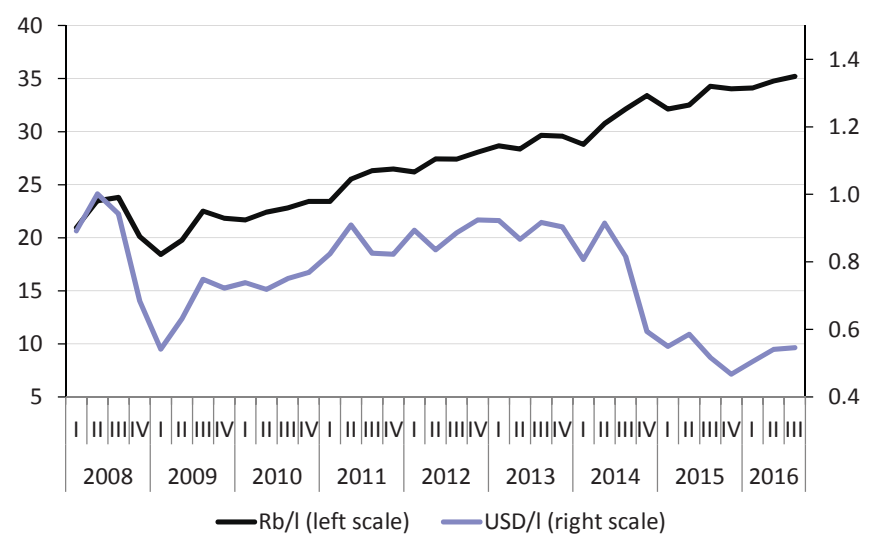

Sources: Rosstat, own calculations.

Fig. 1. Consumer price of gasoline AИ-92 in ruble and dollar terms and the highest taxation burden on petroleum products. According to our calculations, on average across five leading EU countries (Germany, France, Great Britain, Italy, and Spain) the share of indirect taxes in the final price of gasoline currently constitute $65 \%$. The United States boasts of the lowest level of taxation burden: taxes in the gasoline price constitute $20 \%$. In Russia, the share of taxes in the price of gasoline, according to our calculations, constitutes $35-43 \%$. Thus, regarding the tax burden on petroleum products Russia is found in between Europe and US and is close to Canada (also oil exporter as Russia)

Table 4 provides data for the beginning of 2014, which characterize the situation prior to the fall of world oil prices and ruble's devaluation. They attest to a reduction over last two years of prices of gasoline and a noticeable increase of taxes in its price in the countries under review. According to our calculations, the share of taxes in the final price of gasoline in 2014 went up on average across five leading EY countries from 58 to $65 \%$, in the US - from 
Table 3

STRUCTURE OF CONSUMER PRICE OF GASOLINE IN RUSSIA AND OTHER COUNTRIES IN JULY 2016

\begin{tabular}{|l|c|c|c|c|}
\hline & $\begin{array}{c}\text { Consumer } \\
\text { price, USD/I }\end{array}$ & $\begin{array}{c}\text { Taxes on } \\
\text { consumers, USD/I } \\
\text { AИ-92, Regular }\end{array}$ & $\begin{array}{c}\text { Price without } \\
\text { taxes, USD/I }\end{array}$ & $\begin{array}{c}\text { Taxes in consumer } \\
\text { price, \% }\end{array}$ \\
\hline Russia & 0.524 & 0.225 & 0.299 & 42.9 \\
\hline USA & 0.583 & 0.119 & 0.464 & 20.4 \\
\hline Canada & 0.791 & 0.294 & 0.497 & 37.2 \\
\hline Japan & 1.191 & 0.634 & 0.557 & 53.2 \\
\hline Russia & & AИ-95, Premium & & \\
\hline Germany & 0.569 & 0.199 & 0.370 & 35.0 \\
\hline Great Britain & 1.471 & 0.962 & 0.509 & 65.4 \\
\hline France & 1.472 & 1.009 & 0.463 & 68.5 \\
\hline Italy & 1.454 & 0.963 & 0.491 & 68.1 \\
\hline Spain & 1.616 & 1.100 & 0.516 & 57.2 \\
\hline Average across & 1.291 & 0.738 & 0.553 & 65.3 \\
\hline 5 EU countries & 1.461 & 0.954 & 0.506 & \\
\hline
\end{tabular}

Sources: OECD/IEA; Rosstat; own calculations.

Table 4

STRUCTURE OF CONSUMER PRICE OF GASOLINE IN RUSSIA AND OTHER COUNTRIES IN JANUARY 2014

\begin{tabular}{|l|c|c|c|c|}
\hline & $\begin{array}{c}\text { Consumer } \\
\text { price, USD/I }\end{array}$ & $\begin{array}{c}\text { Taxes on } \\
\text { consumers, USD/I } \\
\text { Ah-92, Regular }\end{array}$ & $\begin{array}{c}\text { Price without } \\
\text { taxes, USD/I }\end{array}$ & $\begin{array}{c}\text { Taxes in consumer } \\
\text { price, \% }\end{array}$ \\
\hline Russia & 0.838 & 0.336 & 0.502 & 40.1 \\
\hline USA & 0.875 & 0.111 & 0.764 & 12.7 \\
\hline Canada & 1.150 & 0.364 & 0.786 & 31.7 \\
\hline Japan & 1.523 & 0.609 & 0.914 & 40.0 \\
\hline & & Ah-95, Premium & & \\
\hline Russia & 0.926 & 0.277 & 0.649 & 29.9 \\
\hline Germany & 2.084 & 1.224 & 0.860 & 61.3 \\
\hline Great Britain & 2.138 & 1.311 & 0.827 & 57.5 \\
\hline France & 2.043 & 1.175 & 0.868 & 60.3 \\
\hline Italy & 2.344 & 1.414 & 0.930 & 50.7 \\
\hline Spain & 1.900 & 0.963 & 0.937 & 57.7 \\
\hline Average across & 2.102 & 1.217 & 0.884 & \\
\hline 5 EU countries & & & & \\
\hline
\end{tabular}

Sources: OECD/IEA; Rosstat; own calculations.

13 to $20 \%$, and in Russia - from $30-40 \%$ to $35-45 \%$. Largely this is explained by the fact that with a lower price of gasoline the share of taxes changed according to special rates (on a physical unit of product) goes up.

Comparative analysis demonstrates that consumer prices of gasoline in Russia are currently getting closer to the prices in USA constituting $90 \%$ of the American level. In the meantime, they remain significantly below than in other developed countries: compared to Canada they constitute $66 \%$, Japan $-44 \%$, and in relation to an average level of five leading EU countries $39 \%$. At that, comparing current state with the situation of 2014 we should note a certain reduction of a relative level of prices of gasoline in Russia in comparison with other countries (Table 5). 
Table 5

LEVEL OF CONSUMER PRICE OF GASOLINE IN RUSSIA AGAINST OTHER COUNTRIES, \%

\begin{tabular}{|l|c|c|}
\hline & 2014, January & 2016, July \\
\hline USA & 95.8 & 89.9 \\
\hline Canada & 72.9 & 66.2 \\
\hline Japan & 55.0 & 44.0 \\
\hline Germany & 44.4 & 38.7 \\
\hline Great Britain & 43.3 & 38.7 \\
\hline France & 45.3 & 39.1 \\
\hline Italy & 39.5 & 35.2 \\
\hline Spain & 48.7 & 44.1 \\
\hline EU-5 & 44.1 & 38.9 \\
\hline
\end{tabular}

Sources: OECD/IEA; Rosstat; own calculations.

Thus, Russia preserves a lower level of prices of motor fuel on the domestic market in comparison with developed countries. At the same time, in comparison with the USA the price gap is relatively small and compared to the leading EU countries it is significant. 